\title{
Move over war on transfats; make way for the war on salt
}

$\mathrm{T}$ he place of nasty transfats, formerly the most evil food additive on the planet, has been usurped by a spice that just happens to be the mainstay of the modern Canadian diet: salt. Citing statistics claiming up to 15000 Canadians are dying every year due to excessive sodium consumption, our Federal Health Minister, Tony Clement, has declared war on that lovable but life-threatening spice by launching the Sodium Working Group. His goal? He wants to try to wean us Canadians off the stuff. ${ }^{1}$

While this announcement has the savoury taste of progressive social policy designed to reduce Canada's susceptibility to heart disease, it's ultimately destined to fail. Why? Let's face it. We love salt and so does the Canadian economy that is dependent on us consuming huge amounts of it, hypertension be damned.

The newly formed sodium gestapo are a mere pop-gun against the weapons-grade firepower of saltencrusted industries such as the processed food, fast-food, beer, beverage and pharmaceutical industry who look disdainfully on wimpy government programs and a few do-gooder health associations (including the Canadian Medical Association) who erect roadblocks on the path to profits.

Asking us to give up salt is also sure to generate a huge consumer backlash. For Canadians of British heritage, where salt is the only spot of brightness in the dreariest diet on the planet, taking away our salt would cause many of us to march, Gandhi-like, to the seaside to make our own.

Imagine eating a bucket of unsalted popcorn at the movies. What would then compel you to dish out $\$ 9$ for a regular-sized coke? If the local pub served unsalted peanuts, would you order that third beer? Without the fast food industry deviously salting everything from Big Macs to salad dressings, what would stoke demand for su- persized thirst-quenching solutions? A world sans salt spells bankruptcy everywhere.

Lest we forget, the pharmaceutical companies have a comfy monopoly on treating your high blood pressure and cutting the world's salt intake would threaten a gargantuan market set to surpass nearly $\$ 30$ billion by 20 ro. Let's face it Tony: High blood pressure is Grrrrreeeaaaat.

If declaring ourselves "sodium-free" lowered our collective blood pressure and reduced our need for antihypertensive drugs, watch out as pharma's CEOs set out to squish this strategy like a cockroach. It's not just drug makers, but doctors who make oodles off treating our salt-induced high blood pressure. Checking and rechecking blood pressure makes for fast and uncomplicated doctor visits, and contributes to fleets of BMWs for our nations' physicians. Don't you know that "high blood pressure remained the single biggest reason Canadians visited their physician last year?"2 Can't tamper with that.

After our minister of health's brash announcement to defeat salt, I'm convinced that he is sadly unaware of the forces arrayed against him, including evidence-based medicine. As we speak, research grants are being negotiated, and soon we'll be reading the inevitable studies demonstrating that salt really isn't all that bad, that reducing salt in our diets is not an "evidence-based" way to tackle high blood pressure, and that the spectrum of excellent antihypertensive drugs we Canadians consume already do a relatively good job. So good, in fact, that we should be taking even more of them.

Former Canadian Prime Minister Pierre Trudeau once famously said that the state has no place in the bedrooms of the nation. Let me add a corollary to that: The state has no place in the kitchens of the nation. Canadians don't want Big Brother toying with the taste of the foods we love so much. Med-

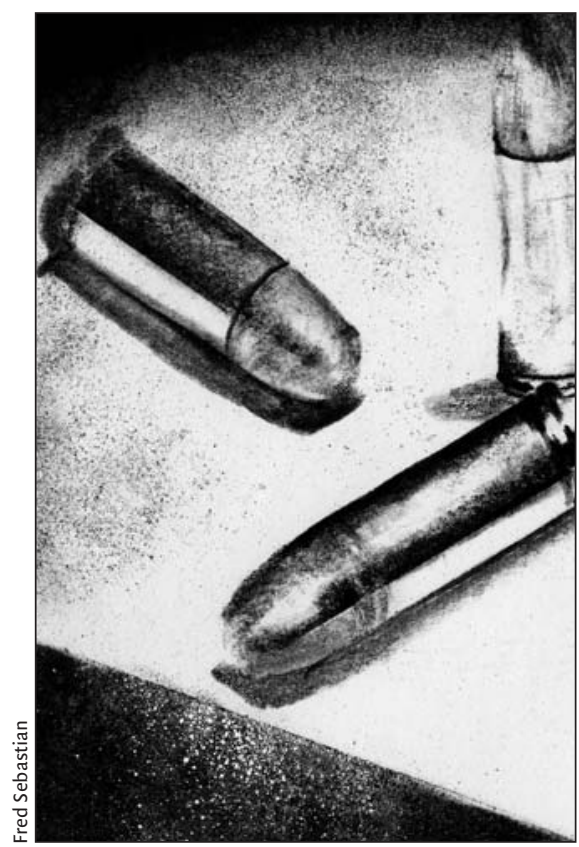

dling in our spice cabinet is unpalatable in a free and democratic society and we should be left alone to consume as much savoury food as we can.

And besides, we like the economy just the way it is: Salty but productive.

\section{Alan Cassels BA MPA \\ Victoria, BC}

Alan Cassels is a drug policy researcher at the University of Victoria. His latest book is The ABC's of Disease Mongering, a Guide to Drugs and Disorders.

\section{REFERENCES}

I. Health Canada. Health Canada tackles cardiovas cular disease through development of sodium working group. [news release]. Ottawa: Health Canada; 2007 Oct 25.

2. IMS Health Canada. Prescription drug purchases by Canadian hospitals and pharmacies reach \$16.57 billion in 2005 March I5, 2006.

Have you got an opinion about this article? Post your views at www.cmaj.ca. Potential Salon contributors are welcome to send a query to salon@cma.ca 